\title{
Correction to: Effect of trigonometric sine, square and triangular wavetype time-periodic gravity-aligned oscillations on Rayleigh-Bénard convection in Newtonian liquids and Newtonian Nanoliquids
}

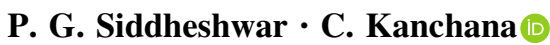

Published online: 3 April 2019

(C) Springer Nature B.V. 2019

Correction to: Meccanica

https://doi.org/10.1007/s11012-019-00957-w

The original article has been updated due to typesetting mistakes made in Section 2.2 Mathematical formulation, Table 1 and in Equation (51).

The original article can be found online at https:// doi.org/10.1007/s11012-019-00957-w.

P. G. Siddheshwar

Department of Mathematics, Bangalore University, Jnanabharathi Campus, Bangalore 560056, India e-mail: mathdrpgs@gmail.com

Present Address:

C. Kanchana $(\bowtie)$

Harbin Institute of Technology, Shenzhen, Nan-

shan District, Shenzhen 518055, Guangdong Province, China

e-mail: kanchana@hit.edu.cn
Publisher's Note Springer Nature remains neutral with regard to jurisdictional claims in published maps and institutional affiliations. 